\title{
Evaluation of Testicular Self-examination Technique and Testis Cancer Knowledge Levels of Final-year Medical Students
}

\author{
(D) Mehmet Uyar MD, (1) Elif Nur Yıldırım MD, (1) Tahir Kemal Şahin MD \\ Necmettin Erbakan University, Meram Faculty of Medicine, Department of Public Health, Konya, Turkey
}

\begin{abstract}
Objective: The aim of this study was to evaluate the adequacy of knowledge regarding testicular self-examination (TSE) in final-year medical students and determine the TSE performance rate among male students.

Materials and Methods: This cross-sectional study was conducted with final-year students in the Meram Medical Faculty of Necmettin Erbakan University in the 2015-2016 academic year. The target population of the study was 233 people and all 202 people who agreed to participate in the survey were included. A data collection form consisting of 29 questions was prepared for the study and was completed under observation. Questions regarding TSE technique and knowledge of TSE and testicular cancer were scored as 1 point for each correct answer and 0 points for incorrect answers. Scores $\geq 6$ points for TSE technique and $\geq 10$ points for TSE and testicular cancer knowledge were regarded as adequate.

Results: The mean age of the participants was $24.12 \pm 1.32$ years; $44.1 \%$ were women and $89.6 \%$ were single. Nearly $25 \%$ of the students reported they knew how to perform TSE and $32.1 \%$ had performed TSE before. History of cancer in a first-degree relative was reported by $17.4 \%$ of the students, but no students had family history of testicular cancer. Fifty-three of the students who claimed to know how to perform TSE, only $34 \%$ $(n=18)$ scored at least 6 points in the TSE technique questions. Evaluation of scores in the TSE and testicular cancer knowledge section showed that $21.3 \%(n=37)$ scored above the 10 point limit.

Conclusion: In our study, it was observed that most of the final-year medical students did not have sufficient information on TSE and testicular cancer, and that TSE rates of male students were low.
\end{abstract}

Keywords: Testicular cancer, testicular self-examination, medical students

\section{Introduction}

Cancer is a serious health problem that causes death without early diagnosis and treatment. It accounts for $25 \%$ of deaths in developed countries and is the second most common cause after ischemic heart disease among all death causes. Cancer is a life-threatening chronic disease responsible for about $10 \%$ of global deaths $(1,2,3)$.

It is well-known that cancer is a difficult disease that affects both the patient and the family physically and emotionally. Despite biomedical developments, cancer is still regarded as synonymous with death, pain, and suffering $(4,5)$. Cancer has many subtypes that can originate from every organ and tissue. One of these is testicular cancer. Testicular cancer is the most common type of cancer in men between the ages of 15-35 (6).
It accounts for $23 \%$ of the cancers in this age group (7) and approximately $1-2 \%$ of all malignant tumors $(8,9)$. Over the past 20 years there has been a 50\% increase in incidence (10). It is considered to be an important public health problem in the United States and continental Europe due to the fact that it is the most common cancer between 15 and 35 years of age (11). Cancers are cancers with high treatment success. The main factors in treatment success are early diagnosis, careful grading at the time of diagnosis, appropriate early treatment approach (surgery, chemotherapy, radiotherapy), very close follow-up, and rescue treatment if necessary (12). Although testicular cancer is a rapidly spreading type of cancer, $85-90 \%$ of patients recover fully if diagnosed early. For this reason, early diagnosis and treatment of testicular cancer is very important (13). The only way to detect testicular cancer early is to regularly conduct

Address for Correspondence: Mehmet Uyar MD, Necmettin Erbakan University, Meram Faculty of Medicine, Department of Public Health, Konya, Turkey Phone: +90 5325755177 E-mail: mehmetuyardr@hotmail.com ORCID ID: orcid.org/0000-0002-3954-7471 Received: 11.07.2018 Accepted: 02.10.2018 
a testicular self-examination (TSE), which increases the chance of catching testicular cancer early by nine to ten fold (14). Testicular cancer affects men at a time when they will have important relationships and be faced with family and career decisions (15). In addition to diagnosis and treatment, doctors also have responsibilities such as raising awareness and taking protective health measures for their patients. For this reason, medical students need to acquire the necessary knowledge and skills before graduation. In this study, it was aimed to evaluate whether final-year medical students had sufficient knowledge about TSE and to determine the rate of TSE performance among the male students.

\section{Materials and Methods}

This research is a cross-sectional study.

\section{Target Population and Sampling}

The study was conducted in final-year students attending the Meram Medical Faculty of Necmettin Erbakan University in the 2015-2016 academic year. During their 6-year medical education, students have theoretical lectures in Term 3, and a two-month pediatric internship in Terms 4 and 6. In Term 5 they have an 8-day pediatric surgery internship and an 11-day urology internship with theoretical and practical lectures about TSE and testicular cancer. The study was conducted on 25 June, 2016. The target population of our research was 233 people. No sample was selected for this study and all 202 persons who agreed to participate in the survey (participation rate: $87 \%$ ) were included. Our rationale for chosing final-year medical students was: a) They receive courses related to this topic during their training; b) They will soon start their medical practice; c) They are in high socio-cultural group; d) They are an accessible group, and most importantly, e) They come from almost all provinces of Turkey. Thus, we believe the sample is representative of the Turkish population.

\section{Data Collection}

A data collection form consisting of 29 questions was developed for this study by scanning the literature. One of the questions is open-ended, while 28 are closed-ended. Seven of the questions are about socio-demographic characteristics, 8 are about the steps of the TSE technique in detail, and 14 assess knowledge level of testicular cancer and TSE (frequency, symptoms and findings, early diagnosis methods). A preliminary data collection form was piloted with 10 people whose data were not included in the analysis of this study. After this pilot study, the final data collection form was written and verbally acknowledged and was completed by all the students at the same time under observation 1 week before graduation. Completion time of the form was approximately 15 minutes.

Dependent variables of the study were having adequate knowledge about TSE, testicular cancer, and TSE technique. Independent variables were age, gender, marital status, history of cancer in first-degree relatives, family history of testicular cancer, reporting knowledge of TSE, and practicing TSE. When evaluating the particpants' responses, each correct answer was worth 1 point and each false answer was given 0 points. According to this scoring system, students could score $0-8$ in the section about TSE technique and 0-14 in the section about TSE and testicular cancer. TSE competence was defined as TSE technique scores of 6 and above and TSE and testicular cancer knowledge scores of 10 or above.

Approval for the study was obtained from the Necmettin University Meram Faculty of Medicine Ethics Committee (2016/417, January 22, 2016).

\section{Statistical Analysis}

The students' responses were transferred to a computerized database. The data were analyzed using SPSS 24.0 package program. Descriptive statistics for numerical data were mean \pm standard deviation (SD), minimum and maximum values and categorical data were expressed in percent (\%) distributions. McNemar test was used to determine the relationships between categorical data; t-test in independent groups, double-point correlation (ETA statistic), and Spearman correlation were used to determine the relationships between numerical data. The statistical significance level was accepted as $<0.05$.

\section{Results}

The average age of the students was $24.12 \pm 1.32$ years. Other characteristics of the final-year students are presented in Table 1. Fifty-three students claimed to know how to perform TSE. When these students were asked about the technique in detail, their mean score was $5.37 \pm 1.55$ (min:1, max:8). The proportion of students with a score of at least 6 points was $34 \%(n=18)$. Six of the students who claimed to know the TSE technique were female, but when asked about the

\begin{tabular}{|c|c|c|}
\hline Characteristics & $\mathbf{n}$ & $\%$ \\
\hline \multicolumn{3}{|l|}{ Sex } \\
\hline Female & 89 & 44.1 \\
\hline Male & 113 & 55.9 \\
\hline \multicolumn{3}{|l|}{ Marital status* } \\
\hline Single & 180 & 89.6 \\
\hline In relationship (engaged/married) & 21 & 10.5 \\
\hline \multicolumn{3}{|l|}{ Cancer in first-degree relatives* } \\
\hline Yes & 35 & 17.4 \\
\hline No & 166 & 82.6 \\
\hline \multicolumn{3}{|l|}{ Testicular cancer in family* } \\
\hline Yes & 0 & 0 \\
\hline No & 200 & 100 \\
\hline \multicolumn{3}{|l|}{ Do you know how to perform TSE?* } \\
\hline Yes & 53 & 26.6 \\
\hline No & 146 & 73.4 \\
\hline \multicolumn{3}{|l|}{ Have you ever performed TSE?** } \\
\hline Yes & 36 & 32.1 \\
\hline No & 76 & 67.9 \\
\hline
\end{tabular}


technique step-by-step in detail, all of those who answered correctly were male. Only 1 student got a perfect score (8) in the TSE technique section. There was no statistically significant relationship between students who claimed they knew how to perform TSE and those who scored at least 6 points when asked about the technical details (McNemar $\times 2=2.616, p=0.106$ ). The students' mean score in the section about TSE and testicular cancer was $8.03 \pm 1.75$ (min:4, max:12). Thirty-seven (21.3\%) of the students surpassed our predetermined threshold of 10 points. None of the students scored perfectly (14 points) in this section. Relationships between the dependent and independent

\begin{tabular}{|c|c|c|c|c|}
\hline & \multicolumn{4}{|c|}{ T-test in independent groups } \\
\hline & \multicolumn{2}{|c|}{$\begin{array}{l}\text { TSE technique } \\
\text { score }\end{array}$} & \multicolumn{2}{|c|}{$\begin{array}{l}\text { TSE and testicular } \\
\text { cancer knowledge } \\
\text { score }\end{array}$} \\
\hline & Mean $\pm S^{*}$ & $p$ & Mean $\pm S D^{*}$ & $\mathbf{p}$ \\
\hline \multirow{2}{*}{$\begin{array}{l}\text { Sex } \\
\text { Female } \\
\text { Male }\end{array}$} & $4.73 \pm 1.51$ & \multirow[t]{2}{*}{0.712} & $8.25 \pm 1.79$ & \multirow[t]{2}{*}{0.175} \\
\hline & $4.81 \pm 1.40$ & & $7.88 \pm 1.73$ & \\
\hline \multirow{2}{*}{$\begin{array}{l}\text { Marital status } \\
\text { Single } \\
\text { In relationship } \\
\text { (engaged/married) }\end{array}$} & $4.79 \pm 1.41$ & \multirow{2}{*}{0.898} & $8.08 \pm 1.71$ & \multirow{2}{*}{0.369} \\
\hline & $4.75 \pm 1.68$ & & $7.70 \pm 2.15$ & \\
\hline \multirow{2}{*}{$\begin{array}{l}\text { Cancer in first-degree } \\
\text { relative } \\
\text { Yes } \\
\text { No }\end{array}$} & $4.63 \pm 1.45$ & \multirow{2}{*}{0.551} & $7.86 \pm 1.72$ & \multirow{2}{*}{0.590} \\
\hline & $4.81 \pm 1.45$ & & $8.06 \pm 1.76$ & \\
\hline \multirow{2}{*}{$\begin{array}{l}\text { Self-reported knowledge } \\
\text { of the TSE technique } \\
\text { Yes, I know } \\
\text { No, I do not know }\end{array}$} & $4.62 \pm 1.48$ & \multirow{2}{*}{0.304} & $8.29 \pm 1.68$ & \multirow{2}{*}{0.239} \\
\hline & $4.86 \pm 1.40$ & & $7.94 \pm 1.78$ & \\
\hline \multirow{2}{*}{$\begin{array}{l}\text { Self-reported TSE } \\
\text { practice** } \\
\text { Yes, I have } \\
\text { No, I have not }\end{array}$} & $4.89 \pm 1.46$ & \multirow{2}{*}{0.771} & $8.31 \pm 1.51$ & \multirow{2}{*}{0.103} \\
\hline & $4.77 \pm 1.38$ & & $7.69 \pm 1.79$ & \\
\hline
\end{tabular}

Table 3. Analysis of relations between dependent and independent variables by double-point correlation (ETA statistic)

\begin{tabular}{|l|l|l|}
\hline \multirow{2}{*}{} & \multicolumn{2}{|l|}{$\begin{array}{l}\text { Double-point } \\
\text { correlation } \\
\text { (ETA statistic) }\end{array}$} \\
\cline { 2 - 3 } & $\begin{array}{l}\text { TSE } \\
\text { technique } \\
\text { score }\end{array}$ & $\begin{array}{l}\text { TSE and testicular } \\
\text { cancer knowledge } \\
\text { score }\end{array}$ \\
\cline { 2 - 3 } & ETA & ETA \\
\hline Sex & 0.013 & 0.048 \\
\hline Marital status & 0.055 & 0.012 \\
\hline Cancer in first-degree relative & 0.036 & 0.039 \\
\hline Self-reported knowledge \\
of TSE technique & 0.046 & 0.049 \\
\hline Self-reported practice of TSE & 0.064 & 0.018 \\
\hline ETA: European technical approval, TSE: Testicular self-examination \\
\hline
\end{tabular}

variables are presented in Table 2 and Table 3. There were no correlations between age and TSE technique score (rho=0.132, $p=0.073$ ), between age and TSE and testicular cancer knowledge score ( $r h o=-0.066, p=0.391$ ), or between TSE technique score and TSE and testicular cancer knowledge score (rho=-0.029, $\mathrm{p}=0.714$ ).

\section{Discussion}

In our study, about one-fourth of the students stated that they knew how to perform TSE, but when asked about the examination technique in detail, only one-third of these students really knew the technique. Many students who believed that they knew the TSE technique did not have accurate information. Only $20 \%$ of the students in our study had adequate TSE and testicular cancer knowledge scores. These low rates may be interpreted as a deficiency in TSE and testicular cancer lessons, both theoretical and practical, in medical education. These low rates may also be related to the fact that TSE and testicular cancer lessons are not adequately addressed during medical education and that students are not educated and trained at the required levels. Other factors may be that the prevalence of testicular cancer is relatively low and that testicular cancer is not included in the national cancer screening program. In previous studies, knowledge of TSE and testicular cancer and TSE practice rates were found to be low $(16,17,18,19,20,21,22)$. In a study conducted by Bektaş et al. (16) on male nursing students, it was found that $91.8 \%$ of the students did not have sufficient knowledge about TSE, 65.6\% did not know how to perform TSE, only $11.6 \%$ practiced TSE. In a study conducted by Altınel (17) and colleagues in Samsun, $93.8 \%$ of the students had never heard of TSE, 3.3\% knew how to perform TSE, 76.6\% wanted information about TSE, and $18.8 \%$ were not able to do TSE correctly. Pour and Çam (18) found that $72.4 \%$ of male nursing students were unaware of TSE and $89.4 \%$ did not know how to perform TSE. Göçgeldi (19) and colleagues found that only $20.7 \%$ of participants had heard of TSE, 8.8\% had performed TSE at least once, and $57.6 \%$ of those who did not practice TSE did not know the TSE technique. Lechner et al. (20) found that $3 \%$ of the participants, Khadra and Oakeshott (21) determined that $28 \%$ of their group, and Rudberg et al. (22) found that $5.6 \%$ of students had heard of TSE before. We were unable to find another study in the literature in which participants were questioned about the TSE technique in detail as in our study. The other studies evaluated whether the participants did or did not know about TSE based on self-reporting. Therefore, we cannot make a comparison with the literature in this respect. However, it should also be taken into account that there may be a discrepancy between participants' claimed knowledge of the TSE technique and their genuine knowledge of the technique, and rates of those who actually know the technique may be much lower than those specified. In our study, all of the 18 students who knew the TSE technique were male. The lack of women who knew TSE technique may be attributed to their indifference to an examination that they cannot apply in their own bodies. In addition, female students may also prefer not to learn an examination that concerns the male reproductive organs because of social value judgements. Although having a 
family member with cancer is expected to raise an individual's sensitivity and awareness of cancer, the results of our study did not support this. Although one-fifth of the students had a firstdegree relative with cancer, there was no relationship between family cancer history and dependent variables. This may also be explained by the fact that none of the students' relatives had testicular cancer. In another study conducted in İzmir, there was no relationship between TSE practice and the presence of cancer in the family (16).

\section{Study Limitations}

In addition to self-reported knowledge and practice of TSE examination technique, we identified students with genuine knowledge of TSE by asking about the technique step-by-step in detail. We also included both female and male medical students in order to evaluate the knowledge of early diagnosis and examination of a male reproductive cancer. These two aspects distinguish our study from others in the literature. Furthermore, due to the fact that the students were from all provinces and regions of Turkey, our results may be generalized to all of Turkey. While evaluating the results of this study, it is useful to consider some limitations. In this study were unable to identify any factors that might be associated with TSE knowledge and practice.

\section{Conclusion}

Most of the final-year medical students in our study did not were not adequately informed about TSE and testicular cancer. It is very important that these students, who are going to be employed as health professionals in the near future, be knowledgeable enough to be able to train their patient groups in TSE. Therefore, the medical curriculum should include detailed lectures on both testicular cancer and TSE that include both practical and theoretical instruction. This training should be evaluated thoroughly after implementation to determine its effectiveness and reshaped according to the results. In addition, we recommend the development of a pre-graduation exam that will serve as a reminder of important topics such as TSE, which provides early recognition of testicular cancer. Conducting similar studies in other medical schools in Turkey will be beneficial.

\section{Ethics}

Ethics Committee Approval: Approval for the study was obtained from the Necmettin Erbakan University Meram Medical Faculty Ethics Committee (2016/417, January 22, 2016).

\section{Informed Consent:}

Peer-review: Externally and internally peer-reviewed.

\section{Authorship Contributions}

Concept: M.U., E.N.Y., Design: M.U., E.N.Y., Data Collection or Processing: M.U., E.N.Y., Analysis or Interpretation: M.U., E.N.Y, T.K.Ş., Literature Search: M.U., E.N.Y, T.K.Ş., Writing: M.U., E.N.Y, T.K.Ş.

Conflict of Interest: No conflict of interest was declared by the authors.
Financial Disclosure: The authors declared that this study received no financial support.

\section{References}

1. Lepore SJ, Coyne JC. Psychological interventions for distress in cancer patients: a review of reviews. Ann Behav Med 2006;32:85-92.

2. Sloan PA, LaFountain P, Plymale $M$, et al. Cancer pain education for medical students: the development of a short course on CD-ROM. Pain Med 2002;3:66-72.

3. Aydoğan Ü, Doğaner $Y C ̧$, Borazan $E$, ve ark. Kanser hastalarında depresyon ve anksiyete düzeyleri ve hastalıkla başa çıkma tutumlarının ilişkisi. Türk Aile Hek Derg 2012;16:55-60.

4. Tavoli A, Mohagheghi MA, Montazeri A, et al. Anxiety and depression in patients with gastrointestinal cancer: does knowledge of cancer diagnosis matter? BMC Gastroenterol 2007;7:28.

5. Güleç G, Büyükkınacı A. Kanser ve psikiyatrik bozukluklar. Psikiyatride Güncel Yaklaşımlar 2011;3:343-367.

6. Akbal C, Tanıdır Y, Türkeri L. Testis kanseri ve infertilite. Bull Urooncol 2006;5:8-11.

7. Bilen C. Böbrek/testis kanserli hastalarda yaşam kalitesi. Bull Urooncol 2005;4:19-23.

8. Parkin DM, Ferlay J, Curado MP, et al. Fifty years of cancer incidence: CI5 I-IX. Int J Cancer 2010;127:2918-2927.

9. Üyetürk U, Üyetürk Ü, Metin A. Bolu ilindeki testis kanserli hastaların retrospektif analizi. Bozok Tıp Derg 2015;5:41-46.

10. Pınar G, Öksüz E, Beder A, Elbaş NÖ. Testis kanseri taramalarında champion' un sağlık inanç modeli ölçeğinin türkçe uyarlamasının güvenirlik ve geçerliliği. Tıp Araştırmaları Dergisi 2011;9:89-96.

11. Kuzgunbay B. Testis tümörü erken tanısında kendi kendine muayenenin yeri: Dünyada ve Türkiye'de durum. Bull Urooncol 2014; 13:127-129.

12. Albers P, Albrecht W, Algaba F, et al. Guidelines on testicular cancer: 2015 Update. Eur Urol 2015;68:1054-1068.

13. Huyghe $E$, Plante $P$, Tonneau PF. Testicular cancer variations in time and space in Europe. Eur Urol 2007;51:621-628.

14. Erdil F, Elbaş NÖ. Cerrahi Hastalıkları Hemşireliği, Üroloji hemşireliği. 4ed. Ankara: Aydoğdu Ofset; 2001;411-412.

15. Basay $S$. Testis kanseri yaşayanlarının yaşam kalitesi ve sosyodemografik özellikler, kansere bağlı değişkenler ve yaşam olayları ile ilişkisi. Bull Urooncol 2006;4:12-14.

16. Bektaş M, Ilya Öş, Küsbeci Ş, Bektaş I. Hemşirelik öğrencilerinin kendi kendine meme muayenesi, kendi kendine testis muayenesi ile HPV aşısı hakkında bilgi ve uygulamaları. Yıldırım Beyazıt Üniversitesi Sağlık Bilimleri Fakültesi Hemşirelik Derg 2014;2:1-11.

17. Altınel B, Avcı IA. Üniversite öğrencilerinin testis kanseri ve kendi kendine testis muayenesi hakkındaki bilgi, inanç ve uygulamaları. TAF Prev Med Bull 2013;12:365-370.

18. Pour HA, Çam R. Erkeklerin kendi kendine testis muayenesi ve testis kanseri hakkında bilgi, tutum ve davranışlarının incelenmesi. F.N. Hem. Derg 2014;22:33-38.

19. Göçgeldi E, Koçak N. Kendi kendine testis muayenesi konusunda genç erişkin erkeklere verilen eğitimin değerlendirilmesi. Gülhane Tıp Derg 2010;52:270-275.

20. Lechner L, Oenema A, Nooijer J. Testicular self examination (TSE) among Dutch young men aged 15-19: determinants of the intention to practice TSE. Health Educ Res 2002;17:73-84.

21. Khadra A, Oakeshott P. Pilot study of testicular cancer awareness and testicular self-examination in men attending two South London general practices. Fam Pract 2002;19:294-296.

22. Rudberg L, Nilsson S, Wikblad K, Carlsson M. Testicular cancer and testicular self-examination: knowledge and attitudes of adolescent Swedish men. Cancer Nurs 2005;28:256-262. 